\title{
MODEL PREDIKSI PENGENDALIAN KOMPLIKASI PENYAKIT PENYERTA PADA PENGGUNA NARKOTIKA DI PALEMBANG
}

\author{
Prediction Model in Controling Comorbidity Complications of \\ Narcotic Users in Palembang
}

\author{
Rico Januar ${ }^{1}$, Feranita Utama ${ }^{2}$, Imelda G.Purba ${ }^{3}$, Bina Melvina ${ }^{4}$ \\ ${ }^{1,2}$ Departemen Epidemiologi Fakultas Kesehatan Masyarakat Universitas Sriwijaya \\ ${ }^{3}$ Departemen Kesehatan Lingkungan Fakultas Kesehatan Masyarakat Universitas Sriwijaya. \\ ${ }^{4}$ Program Studi Keperawatan Fakultas Kedokteran Universitas Sriwijaya \\ (ciocianathan@gmail.com)
}

\begin{abstract}
ABSTRAK
Penyalahgunaan narkotika dapat mengakibatkan komplikasi fisik, psikologis dan beban ekonomi keluarga. Semakin lama menggunakan narkotika dan tidak menjalani rehabilitasi akan membuat kecanduan yang berat. Pengguna narkotika dengan adiksi berat akan berdampak juga terhadap beratnya penyakit yang dialami dan lamanya menjalani rehabilitasi. Beban penyakit yang diakibatkan ketergantungan narkotika akan berdampak terhadap kondisi sosial ekonomi sendiri dan keluarga. Penelitian ini bertujuan untuk menghasilkan suatu model prediksi terhadap pengendalian komplikasi penyakit penyerta pengguna narkotika. Desain penelitian ini adalah cross sectional study dengan populasi penelitian adalah semua pengguna narkotika baik pengguna narkotika suntik dan narkotika bukan suntik. Sampel dalam penelitian ini adalah pecandu narkotika yang menggunakan jenis narkotika dengan total sampel 211 orang. Hasil penelitian ini menunjukan bahwa tidak melakukan hubungan seksual yang berisiko akan mencegah pengguna narkotika mengalami komplikasi penyakit penyerta dengan $\mathrm{p}=0,04, \mathrm{OR}$ Adj= 0,47 dengan interval kepercayaan $0,22-0,99$ setelah dikontrol jenis kelamin dan status perkawinan. Temuan ini memberikan informasi bahwa hubungan seksual berisiko harus dihindari. Untuk itu diharapkan dukungan keluarga untuk lebih perduli, aktif merekomendasikan untuk mengikuti rehabilitasi dan dukungan pemerintah untuk melakukan penjangkauan dengan memberi informasi yang tepat bahwa mereka yang secara sadar melapor tidak akan ditangkap untuk masuk penjara, tetapi direkomendasikan untuk direhabilitasi.
\end{abstract}

Kata kunci : Komplikasi, narkotika, perilaku seksual

\section{ABSTRACT}

Narcotics abuse can lead to physical, psychological and family economic burden. The longer the use of narcotics and not undergoing rehabilitation will make a heavy addiction. Drug users with heavy addictions will also have an impact on the severity of the illness and the length of rehabilitation. The burden of illness due to narcotic dependence will have an impact on the socio-economic conditions of the family itself. This study aims to produce a prediction model for controlling complications of illness along with narcotics users. The design of this study is cross-sectional study with the study population are all users of narcotics both injecting drug users and injecting narcotics. The sample in this study is narcotic addicts who use narcotics with a total sample of 211 people. The results of this study indicate that no risky sexual intercourse will prevent narcotic users from complicating comorbidities with $p=0.04$, OR Adj $=0.47$ with confidence interval 0.22 to 0.99 after sex control and status marriage. This finding provides information that risky sexual intercourse should be avoided, so family support is expected to be more concerned, actively recommends to follow rehabilitation and government support to outreach by providing appropriate information that those who consciously report will not be arrested for going to jail but recommended for rehabilitation.

Keywords : Complications, narcotics, sexual behavior 


\section{PENDAHULUAN}

Penyalahgunaan narkotika di Indonesia sudah menjadi masalah kesehatan masyarakat yang memerlukan perhatian yang serius oleh Pemerintah. Sifat narkotika dapat mengakibatkan kecanduan bagi penggunanya. Data Pencegahan dan Pemberantasan Penyalahgunaan dan Peredaran Gelap Narkoba (P4GN) menunjukkan jumlah pengguna narkotika yang kecanduan berat sekitar $153-300$ juta atau dengan prevalensi 3,4 - 6,6\%. Penyalahguna narkotika mayoritas pada usia produktif dengan usia 21-30 tahun sebesar 47,55\% dengan proporsi laki-laki jauh lebih besar dibandingkan dengan perempuan yaitu $75,41 \%$. Jenis zat yang disalahgunakan adalah multiple zat atau lebih dari satu zat sebesar $47,92 \%$, konsumsi shabu $(31,03 \%)$ dan ekstasi $(15,69 \%){ }^{2}$

Narkotika memberikan dampak buruk terhadap kesehatan penggunanya. Pengguna narkotika suntik dapat terinfeksi virus seperti hepatitis, HIV-AIDS $^{3}$ dan dapat menginisiasi teman yang lain untuk menggunakannya secara bersamasama. ${ }^{4}$ Prevalensi hepatitis $\mathrm{C}$ di antara pengguna narkotika suntik berkisar antara 45\% sampai 95\% di kota-kota di seluruh dunia. ${ }^{5-7}$ Dampak buruk narkotika mengakibatkan kerugian yang besar bagi diri sendiri, keluarga dan masyarakat serta berdampak terhadap rendahnya kualitas hidup seseorang khususnya yang berhubungan dengan kesehatannya. $^{8}$

Kualitas hidup yang rendah berhubungan dengan tingginya angka kematian dan seringnya berobat ke fasilitas kesehatan. ${ }^{9-11}$ Kualitas kesehatan yang buruk akan mengakibatkan menurunnya produktifitas yang berdampak terhadap kondisi sosial dan ekonomi keluarga. Keadaan ini semakin meningkatkan beban bagi diri sendiri dan keluarga pengguna narkotika. ${ }^{12,13}$ Untuk meningkatkan kualitas hidup para pecandu narkotika perlu dilakukan upaya, seperti pengurangan dampak buruk akibat narkotika. Program-program pengurangan dampak buruk seperti tidak menggunakan jarum suntik secara bersama-sama, dam program metadon. Femke A.E menyarankan bahwa perlunya dukungan yang sistematis dan komprehensif dalam meningkatkan kepatuhan dalam menjalankan program pengurangan dampak buruk akibat narkotika. ${ }^{14}$

Kepatuhan dalam mengikuti program pe- ngurangan dampak buruk dapat menurunkan tingkat ketergantungan. Penggunaan narkotika berhubungan erat dengan perilaku seks berisiko seperti melakukan seksual sebelum menikah, bergonta ganti mitra seksual dan tidak menggunakan alat kontrasepsi. Penelitian Damayanti mengungkapkan bahwa remaja yang pernah melakukan hubungan seksual sebelum menikah berisiko lebih tinggi untuk menggunakan narkotika dan alkohol. ${ }^{15}$

Pengguna narkotika dalam waktu lama berpotensi untuk mengidap penyakit hepatitis dan HIV-AIDS. Penularan penyakit ini dapat melalui penggunaan narkotika suntik secara bersama-sama dan perilaku seksual yang tidak aman (berisiko). Pengguna narkotika dengan status HIV memiliki peluang empat kali untuk mengalami depresi dibandingkan dengan yang tidak depresi. Self efficacy merupakan prediktor terhadap keyakinan dan kemampuan seseorang bernegosiasi dalam praktik seks aman, pencegahan AIDS, dan keterampilan dalam melindungi diri dari penyakit menular. Self efficacy yang tinggi dapat membantu mengatur kehidupan sehari-hari dengan HIV, mengurangi depresi dan tekanan dari lingkungan. ${ }^{16}$

Dampak buruk akibat kecanduan narkotika dalam waktu lama juga dapat mengakibatkan perubahan pada fungsi otak. Perbedaan biologis yang jelas dari otak orang yang mengalami masalah adiksi (kecanduan), dibandingkan dengan otak orang yang tidak mengalami masalah adiksi. Ma et al., mengungkapkan bahwa ketergantungan obat mengakibatkan fungsi dan struktur otak menjadi tidak normal. Perubahan pada otak juga terjadi pada orang yang tidak ketergantungan heroin. Perubahan fungsi otak dinilai dengan dengan menggunakan Positron Emission Tomography (PET) dan Magnetic Resonance Imaging (MRI). ${ }^{17,18}$ Tujuan penelitian adalah untuk menghasilkan model prediksi pengendalian komplikasi penyakit penyerta (komorbiditas) pada penyalahguna narkotika di Kota Palembang.

\section{BAHAN DAN METODE}

Penelitian ini menggunakan desain cross sectional dengan mengukur faktor determinan dan komplikasi penyakit penyerta secara bersamaan. Penelitian ini dilakukan di Rumah Sakit Ernaldi Bahar yang fokus menangani orang-orang 
yang kecanduan narkotika, yayasan Mitra Mulia, yayasan Ar Rahman, dan Badan Narkotika Nasional Propinsi. Penelitian ini dilakukan selama 3 bulan dari bulan September - November dengan populasi studi adalah semua pecandu narkotika baik yang menjalani rawat jalan dan rawat inap. Sampel dalam penelitian ini berjumlah 211 orang dengan kriteria inklusi adalah pasien pecandu narkotika yang bersedia di wawancara secara sadar dan tidak mengalami gangguan mental. Kriteria eksklusi dalam penelitian ini adalah pasien yang mengalami sakau. Teknik pengambilan sampel dilakukan dengan cara total sampel (seluruh responden) di tempat penelitian.

Analisis data yang digunakan dalam penelitian ini adalah analisis univariat untuk memberikan gambaran dari variabel-variabel yang diteliti, analisis bivariat untuk menguji hubungan antara variabel-variabel independen dengan variabel dependen menggunakan uji chi square, dan analisis multivariat untuk menjelaskan sifat variabel prediktor dan kontribusi relatif mereka dalam menjelaskan variabel dependen. Dalam penelitian ini, variabel dependen bersifat dikotom, oleh karena itu analisis regresi logistik digunakan untuk memprediksi hubungan antara variabel dependen dan variabel independen. Instrumen yang digunakan dalam penelitian untuk mengetahui faktor determinan adalah kuesioner yang terstruktur sudah di validasi, sedangkan untuk mengetahui komplikasi penyakit penyertanya dengan melihat dokumen (rekam medis) responden.

\section{HASIL}

Hasil penelitian berdasarkan karakteristik demografi menunjukkan bahwa mayoritas responden berusia $>30$ tahun dengan tingkat pendidikan tamat SLTA, status belum menikah, pekerjaan karyawan swasta/buruh dan tingkat penghasilan antara Rp.1,5-3 juta. (Tabel 1). Berdasarkan gambaran beban ekonomi keluarga, pengguna narkoba mengeluarkan biaya yang sangat besar selama menggunakan untuk biaya membeli narkoba dan uang yang dikeluarkan untuk berobat ke fasilitas kesehatan (Tabel 2). Berdasarkan analisis bivariat menunjukan bahwa terdapat dua variabel yang memenuhi kriteria kandidat model multivariat dengan nilai $p<0,25$ yaitu variabel perilaku seksual berisiko $(p=0,06)$ dan status perkawinan $(p=0,17)$

\begin{tabular}{lcc} 
Tabel 1. Distribusi Status Demografi Responden \\
\hline Status Demografi Responden & $\mathbf{n}=\mathbf{2 1 1}$ & $\mathbf{n}$ \\
\hline Usia & & \\
13-18 Tahun & 40 & 19,0 \\
19-24 Tahun & 59 & 28,0 \\
25-30 Tahun & 40 & 19,0 \\
> 30 Tahun & 72 & 34,0 \\
Tingkat Pendidikan & & \\
Tidak Sekolah & 5 & 2,4 \\
SD & 24 & 11,4 \\
SLTP & 49 & 23,6 \\
SLTA & 109 & 51,7 \\
Akademi/Perguruan Tinggi & 24 & 11,4 \\
Pekerjaan & & \\
Tidak Bekerja & 33 & 15,6 \\
Pelajar & 29 & 13,7 \\
Mahasiswa & 8 & 3,8 \\
Karyawan swasta/buruh & 77 & 36,5 \\
Wiraswasta & 35 & 16,6 \\
Ibu Rumah Tangga & 8 & 3,8 \\
Pensiunan & 1 & 0,5 \\
PNS & 4 & 1,9 \\
Dan lain-lain & 16 & 7,6 \\
Penghasilan & & \\
< Rp. 500.000 & 5 & 3,7 \\
Rp. 500.000 s/d Rp. 1.500.000 & 37 & 27,2 \\
Rp. 1.500.000 s/d Rp. 3.000.000 & 54 & 39,7 \\
Rp. 3.000.000 s/d Rp. 4.500 .000 & 12 & 8,8 \\
> Rp. 4.500.000 & 28 & 20,6 \\
Status Perkawinan & & \\
Belum Menikah & 133 & 63 \\
Menikah & 59 & 28 \\
Duda/Janda & 11 & 5,2 \\
Cerai/Pisah & 8 & 3,8 \\
\hline & & \\
& & \\
\hline & &
\end{tabular}

(Tabel 3).

Berdasarkan analisis multivariat diperoleh bahwa tidak melakukan hubungan seksual yang berisiko akan mencegah pengguna narkotika mengalami komplikasi penyakit penyerta dengan $(\mathrm{p}=0,04, \mathrm{OR}$ Adj $=0,47$ dengan confident interval $0,22-0,99$ setelah dikontrol jenis kelamin status perkawinan (Tabel 4).

\section{PEMBAHASAN}

Hasil penelitian menunjukkan bahwa $52,6 \%$ pengguna narkotika telah melakukan hubungan seksual sebelum menikah. Responden yang melakukan hubungan seksual sebelum menikah dilakukan dengan pasangannya (pacarnya) lebih dari $80 \%$, sedangkan yang melakukan hubungan 
Tabel 2. Gambaran Beban Ekonomi Responden

\begin{tabular}{lc}
\hline \multicolumn{1}{c}{ Variabel } & Mean (Minimum-Maksimum (Rp)) \\
\hline Beban ekonomi keluarga & \\
Biaya yang dikeluarkan pertama kali membeli narkoba & $42.443(2000-500.000)$ \\
Biaya yang dihabiskan untuk membeli narkoba selama seminggu & $870.663(10.000-5.000 .000)$ \\
Biaya yang dikeluarkan selama menggunakan narkoba & $7.661 .005(100.000-200.000 .000)$ \\
Biaya transportasi ke fasilitas kesehatan dalam sebulan & $31.786(5000-800.000)$ \\
Biaya berobat ke fasilitas kesehatan selama menggunakan narkoba & $693.076(0-7.000 .000)$ \\
Frekuensi kunjungan ke Pelayanan kesehatan (kali) & $5(1-60)$ \\
Jumlah kunjungan ke fasilitas kesehatan untuk berobat selama & \\
menggunakan narkoba & \\
\hline
\end{tabular}

Tabel 3. Hubungan Determinan Penggunaan Narkoba dengan Komorbiditas

\begin{tabular}{|c|c|c|c|}
\hline \multirow{3}{*}{ Variabel } & \multicolumn{2}{|c|}{ Komorbiditas } & \multirow{3}{*}{$\mathbf{p}$} \\
\hline & Tidak & Ya & \\
\hline & $\mathbf{n}(\%)$ & $\mathbf{n}(\%)$ & \\
\hline \multicolumn{4}{|c|}{ Lama menggunakan Narkoba $($ Median $=23)$} \\
\hline$<6$ bulan & $3(10,7)$ & $23(89,3)$ & 0,58 \\
\hline$\geq 6$ bulan & $32(17,5)$ & $151(82,5)$ & \\
\hline \multicolumn{4}{|l|}{ Merokok } \\
\hline Tidak & $3(14), 3$ & $18(85,7)$ & 1,000 \\
\hline Ya & $18(72)$ & $7(28)$ & \\
\hline \multicolumn{4}{|l|}{ Minum alkohol } \\
\hline Tidak & $10(18,9)$ & $43(81.1)$ & 0,76 \\
\hline Ya & $25(15,8)$ & $133(84,2)$ & \\
\hline \multicolumn{4}{|l|}{ Perilaku seksual berisiko } \\
\hline Tidak & $22(22)$ & $78(78)$ & 0,06 \\
\hline Ya & $13(11,7)$ & $98(88,3)$ & \\
\hline \multicolumn{4}{|l|}{ Status perkawinan } \\
\hline Tidak & $6(10,2)$ & $53(89,8)$ & 0,17 \\
\hline Ya & $29(19,1)$ & $123(80.9)$ & \\
\hline
\end{tabular}

Tabel 4. Hasil Analisis Multivariat Regresi Logistik Model Akhir

\begin{tabular}{lcccc}
\hline \multicolumn{1}{c}{ Hubungan Seksual } & Koefisien (B) & Nilai p & OR & 95\% IK \\
\hline Ya & 0,75 & 0,04 & 0,47 & $0,22-0,99$ \\
Tidak & & & & \\
\hline
\end{tabular}

seksual dengan Pekerja Seks Komersial (PSK) sebesar $36,9 \%$ dan mayoritas usia mereka kurang dari 20 tahun. Hal ini menunjukkan bahwa pe-rilaku seksual mereka sangat mendukung untuk mengalami komplikasi penyakit penyerta. Perilaku berisiko mereka juga didukung bahwa saat mereka melakukan hubungan seksual tidak menggunakan alat kontrasepsi. Berdasarkan analisis multivariat menunjukan bahwa tidak melakukan hubungan seksual yang berisiko merupakan fak- tor yang dapat mencegah terjadinya komplikasi penyakit penyerta dengan nilai odds ratio 0,47 dengan nilai interval kepercayaan $0,22-0,99$. Penelitian Nwagu mengungkapkan bahwa remaja pengguna narkotika memiliki kecenderungan tidak dapat mengendalikan hasrat seksual, sehingga mereka melakukan perilaku seksual berisiko seperti melakukan pemerkosaan. Untuk mencegah perilaku seksual berisiko ini, diperlukan intervensi pada usia dini khususnya dikalangan pecandu 
narkotika. ${ }^{19,20}$ Menurut penelitian Rico, menunjukan bahwa pengguna narkotika yang melakukan hubungan seksual pada umur $\leq 17$ tahun berisiko 6,74 kali untuk melakukan perilaku seksual berisiko dibandingkan dengan yang melakukan hubungan seksual $>17$ tahun. ${ }^{21}$

Perilaku seksual berisiko adalah melakukan hubungan seksual sebelum menikah, berganti-ganti pasangan dan tidak menggunakan alat kontrasepsi. ${ }^{22}$ Perilaku berisiko yang dilakukan para pecandu narkotika mendukung mereka untuk mengalami komplikasi atau penyakit penyerta yang diakibatkan dampak buruk narkotika. Seorang pengguna narkotika yang sudah kecanduan mengalami gangguan kepribadian seperti cemas, depresi, perubahan kualitas hidup, penurunan interaksi personal, penurunan kepuasan terhadap kehidupannya sehari-hari dan terganggunya kesehatan sosial dan mental. ${ }^{23,24}$

Penggunaan narkotika dalam waktu lama dapat mengakibat berbagai hal negatif antara lain terlibat kriminalitas, kesakitan bahkan sampai kematian. Pengguna narkotika dalam waktu lama selain mengakibatkan rendahnya self efficacy, juga berpotensi untuk mengidap penyakit $\mathrm{Tb}$ paru, hepatitis dan HIV-AIDS. ${ }^{16}$ Penelitian Smyth et al., mengungkapkan tingginya kematian pada pengguna heroin karena HIV-AIDS. ${ }^{25}$ Pecandu narkotika dengan komorbiditas mengakibatkan rendahnya self efficacy.

Penelitian Rodkjaer et al., mengungkapkan bahwa ada hubungan yang signifikan antara self efficacy dengan individu yang hidup dengan HIV. Individu dengan self efficacy yang tinggi tidak mengalami depresi karena berani terbuka dengan lingkungannya bahwa dia hidup dengan HIV. Individu yang tertutup dengan status HIV-nya memiliki peluang empat kali untuk mengalami depresi dibanding dengan yang terbuka dengan status HIV-nya. Self efficacy yang tinggi dapat membantu mengatur kehidupan sehari-hari dengan HIV, mengurangi depresi dan tekanan dari lingkungan. ${ }^{16}$

Menurut McKellar et al., pengguna jarum suntik yang terinfeksi Hepatitis C memiliki self efficacy yang rendah. Hal ini mengakibatkan para pengguna jarum suntik dengan mudah untuk menggunakan jarum suntik secara bersama-sama, kurangnya kesadaran dalam melakukan penyuntikan yang aman, peralatan yang tidak steril dan tidak dapat meyakinkan orang lain untuk melakukan penyuntikan dengan aman. ${ }^{26}$

Kecanduan dalam waktu lama dapat mempengaruhi fungsi otak pecandu. Penelitian telah membuktikan bahwa terdapat perbedaan biologis yang jelas dari otak orang yang mengalami masalah adiksi (kecanduan), dengan otak dari orang yang tidak mengalami masalah adiksi. Hasil penelitian Ma et al., dengan menggunakan Positron Emission Tomography (PET) dan Magnetic Resonance Imaging (MRI) mengungkapkan bahwa ketergantungan obat mengakibatkan fungsi dan struktur otak menjadi tidak normal. Perubahan pada otak juga terjadi pada orang yang tidak ketergantungan heroin lagi. ${ }^{17,18}$

\section{KESIMPULAN DAN SARAN}

Untuk mencegah komplikasi fisik dan beratnya beban keluarga, pengguna narkotika harus menghindari perilaku berisiko. Hasil utama dari penelitian ini adalah tidak melakukan hubungan seksual berisiko sebagai faktor protektif. Hasil ini menunjukkan perlunya pengguna narkotika sadar akan risiko yang diakibatkan hubungan seksual yang tidak aman. Hasil penelitian ini juga menunjukkan bahwa mayoritas pengguna narkotika melakukan hubungan seksual berisiko dengan pacarnya yaitu tidak menggunakan kondom dan masih melakukan hubungan seksual dengan pekerja seks komersil. Untuk itu diperlukan dukungan keluarga untuk lebih perduli dan aktif merekomendasikan untuk mengikuti rehabilitasi dan dukungan pemerintah untuk melakukan penjangkaun dengan memberi informasi yang tepat bahwa mereka yang secara sadar melapor tidak akan ditangkap untuk masuk penjara tetapi direkomendasikan untuk direhabilitasi.

\section{DAFTAR PUSTAKA}

1. BNN. Jurnal Data P4GN. Pencegahan, Pemberantasan Penyalahgunaan dan Peredaran Gelap Narkoba. Jakarta; 2012.

2. BNNP. Data Penyalahguna Narkotika. Badan Narkotika Nasional Provinsi Sumatera Sela$\tan ; 2014$.

3. Mathers BM, Degenhardt L, Phillips B, Wiessing L, Hickman M, Strathdee SA, et al. Global Epidemiology of Injecting Drug Use and HIV among People Who Inject Drugs: A System- 
atic Review. The Lancet.372(9651):1733-45.

4. Bluthenthal RN, Wenger L, Chu D, Lorvick J, Quinn B, Thing JP, et al. Factors Associated with Being Asked to Initiate Someone into Injection Drug Use. Drug and Alcohol Dependence. 2015;149:252-8.

5. MJ. A. Prevention of Spread of Hepatitis C. Hepatology 2002;36(5):S93-S98 [PubMed: 12407581].

6. Dore GJ LM, MacDonald M, Kaldor JM . Epidemiology of Hepatitis C Virus Infection in Australia. J Clin Virol 2003;26(2):171-184 [PubMed: 12600649].

7. H. H. Hepatitis C Virus Transmission Dynamics in Injection Drug Users. Subst Use Misuse 1998;33:1197-1212 [PubMed: 9596383.

8. Donovan D MM, Cisler RA, Longabaugh R, Zweben A. Quality of Life as An Outcome Measure in Alcoholism Treatment Research. J Stud Alcohol. 2005;(Suppl):119-139 Discussion 92-3.

9. Brindis $\mathrm{CD}, \&$ Theidon, K. S. The Role of Case Management in Substance Abuse Treatment Services for Women and Their Children. Journal of Psychoactive Drugs. 1997;29:7988.

10. McLellan AT, Lewis, D. C., O'Brien, C. P., \& Kleber, H. D. Drug Dependence, A Chronic Medicalillness Implications for Treatment, Insurance, and Outcomes Evaluation. Journal of the American Medical Association. 2000;284:1689-1695.

11. Degenhardt L, Bucello C, Mathers B, Briegleb C, Ali H, Hickman M, et al. Mortality Among Regular or Dependent Users of Heroin and Other Opioids: A Systematic Review and Meta-Analysis Of Cohort Studies. Addiction. 2011;106(1):32-51.

12. Wall M, Schmidt E, Sarang A, Atun R, Renton A. Sex, Drugs And Economic Behaviour in Russia: A study of Socio-Economic Characteristics of High Risk Populations. International Journal of Drug Policy.22(2):133-9.

13. Horyniak D, Higgs P, Jenkinson R, Degenhardt L, Stoové M, Kerr T, et al. Establishing The Melbourne Injecting Drug User Cohort Study (MIX): Rationale, Methods, and Baseline and Twelve-Month Follow-up Results. Harm Reduction Journal. 2013;10:11.
14. Lambers FAE, Stolte IG, van den Berg CHSB, Coutinho RA, Prins M. Harm Reduction Intensity Its Role in HAART Adherence amongst Drug Users in Amsterdam. International Journal of Drug Policy. 2011;22(3):210-8.

15. Damayanti R. Peran Biopsikososial terhadap Perilaku Berisiko Tertular HIV pada Remaja SLTA di DKI (Disertasi). Fakultas Kesehatan Masyarakat: Indonesia; 2007.

16. Rodkjaer L, Chesney MA, Lomborg K, Ostergaard L, Laursen T, Sodemann M. HIV Infected Individuals with High Coping Self Efficacy are Less likely to Report Depressive Symptoms: A Cross-Sectional Study from Denmark. International Journal of Infectious Diseases. 2014;22(0):67-72.

17. Ma N, Liu Y, Fu XM, Li N, Wang CX, Zhang $\mathrm{H}$, et al. Abnormal Brain Default-Mode Network Functional Connectivity in Drug Addicts. PloS one. 2011;6(1):e16560.

18. Wang X, Li B, Zhou X, Liao Y, Tang J, Liu $\mathrm{T}$, et al. Changes in Brain Gray Matter in Abstinent Heroin Addicts. Drug and Alcohol Dependence. 2012;126(3):304-8.

19. Nwagu EN. Alcohol and Drug Usage; and Adolescents' Sexual Behaviour in Nigeria. Health Promotion International. 2015.

20. Baldwin P, Shrestha R, Potrepka J, Copenhaver M. The Age of Initiation of Drug Use and Sexual Behavior May Influence Subsequent HIV Risk Behavior: A Systematic Review. ISRN AIDS. 2013;2013:17.

21. Sitorus RJ, Natalia M. Perilaku Seksual Berisiko Pengguna Narkotika. Kesmas : National Public Health Journal. 2015;9(4):348-52.

22. Kemenkes. Strategi Promosi Pencegahan Penyalahgunaan Napza di Indonesia. Jakarta: Departemen Kesehatan ; 2001.

23. Hasin D, Liu X, Nunes E, McCloud S, Samet $S$, Endicott J. Efects of Major Depression on Remission and Relapse of Substance Dependence. Archives of General Psychiatry. 2002;59(4):375-80.

24. Brown S, Jun MK, Min MO, Tracy EM. Impact of Dual Disorders, Trauma, and Social Support on Quality of Life Among Women in Treatment for Substance Dependence. Journal of Dual Diagnosis. 2013;9(1):61-71.

25. Smyth B, Hoffman V, Fan J, Hser Y-I. Years 
of Potential Life Lost among Heroin Addicts 33 Years after Treatment. Preventive Medicine. 2007;44(4):369-74.

26. McKellar J, Ilgen M, Moos BS, Moos R.
Predictors of Changes in Alcohol-Related Self-Efficacy Over 16 Years. Journal of Substance Abuse Treatment. 2008;35(2):148-55. 